\title{
TANGGUNG GUGAT DEBITOR TERHADAP HILANGNYA HAK ATAS TANAH DALAM OBYEK JAMINAN HAK TANGGGUNGAN
}

\author{
Fani Martiawan Kumara Putra
}

\author{
Fakultas Hukum Universitas Wijaya Kusuma \\ fanimartiawan@gmail.com
}

\begin{abstract}
Security interest, provided by the debtor, is an implementation of prudential principle by the bank as the creditor. Security interest is a right in rem, thus will give a priority to the creditor to enjoy settlement from the property in which the security interest is laid down. However, Hak Tanggungan over land right, will be extinct if the land right is extinct. The protection over the creditor will be a main issue on the discussion. This article will discuss on the legal protection over the creditor and the liability of the debtor if the land right, as the object of the Hak Tanggungan, is extinct.
\end{abstract}

Keywords : security interest, right in rem, hak tanggungan.

\begin{abstract}
Abstrak
Pengikatan suatu benda khusus sebagai suatu jaminan, merupakan wujud dari prinsip kehati-hatian pihak kreditor dalam perjanjian hutang piutang, dan hal ini akan melahirkan hak kebendaan. Hak kebendaan semacam ini tergolong hak kebendaan yang memberikan jaminan, dan mempunyai beberapa keistimewaan tersendiri, antara lain preferensi kreditor, adanya prioritas, dan yang terpenting adalah eksekusinya yang dapat terbilang lebih mudah dan pasti, yaitu dengan diaturnya parate eksekusi. Hak tanggungan sebagai bentuk hak kebendaan ini bisa hapus karena beberapa hal, antara lain karena hilangnya hak atas tanah yang sedang dijadikan obyek jaminan. Perlindungan kreditor dan tanggung gugat debitor disini kerapkali menjadi masalah hingga proses eksekusi. Dibahas dalam tulisan ini mengenai upaya yang dapat ditrempuh kreditor agar mendapatkan perlindungan hukum, dan juga bentuk tanggung gugat debitor dalam hal hapusnya hak atas tanah yang dibebani Hak Tanggungan.
\end{abstract}

Kata kunci : jaminan, hak kebendaan, hak tanggungan.

\section{Pendahuluan}

Manusia sebagai suatu sosok yang tidak dapat hidup sendiri dan kegiatan hidupnya itu kerapkali penuh dengan perhitungan untung dan rugi, membawa manusia itu saling mengikatkan diri dengan orang lain, yang mana peristiwa ini dikenal dengan nama perikatan. Perikatan yang sering terjadi diantara masyarakat itu kerapkali lahirnya didominasi oleh peristiwa perjanjian-perjanjian yang dibuat oleh para pihak, selain perjanjian jual beli, perjanjian yang seringkali dibuat dan disepakati para pihaknya adalah perjanjian hutang-piutang, yang mana sudah barang tentu perjanjian hutang-piutang ini dilakukan untuk menopang kebutuhan 
persediaan dana yang sangat besar. Pada prinsipnya dalam kehidupan seseorang maupun perusahaan itu tidaklah terlepas dari transaksi hutang-piutang yang mana di latarbelakangi untuk pemenuhan suatu kebutuhan.

Penyaluran kredit kepada masyarakat sebagai pelaku usaha, selaku kreditor, penuh dengan resiko kemacetan dalam pelunasannya. Pemenuhan kebutuhan yang dilatarbelakangi dengan hutang, karena membeli barang dengan cara mencicil, sering dijumpai keadaan pembayarannya kurang atau tidak lancar (hutangnya menjadi macet). Menyadari bahwa dana yang keluar dan masuk dalam kegiatan perkreditan itu adalah dana yang sangat besar, dan didasari atas pentingnya dan sungguh beresikonya kegiatan perkreditan itu, maka sudah semestinya kegiatan perkreditan tersebut didampingi dengan kegiatan penjaminan, hal ini dikarenakan perkembangan ekonomi dan perdagangan itu akan pasti diikuti oleh perkembangan kebutuhan akan kredit, dan pemberian fasilitas kredit ini memerlukan jaminan demi keamanan pemberian kredit tersebut. Maka sudah sepantasnya jika pemberi dan penerima kredit, serta pihak lain yang terkait dalam suatu kegiatan perkreditan itu mendapat perlindungan melalui suatu lembaga jaminan yang dapat memberikan kepastian hukum bagi semua pihak.

Sumber kredit yang diperoleh dari ikut sertanya lembaga bank dan keuangan lainnya baik nasional maupun asing, sangat bergantung pada tersedianya suatu sistem jaminan yang pasti. Pemberian fasilitas pinjaman atau kredit dalam usaha pengadaan benda-benda yang membutuhkan dana sangat besar itu selalu mensyaratkan tersedianya jaminan yang pasti bagi pihak pemberi kredit maupun penjual demi keamanan modalnya dan kepastian hukum.

Dalam peraturan perundang-undangan, telah diberikan pengaman kepada kreditor dalam menyalurkan kredit kepada pihak debitor, yakni dengan adanya jaminan umum menurut yang mana diatur dalam Pasal 1131 jo. 1132 Burgerlijk Wetboek (selanjutnya disebut BW), yang menentukan bahwa semua harta kekayaan (kebendaan) debitor baik bergerak maupun tidak bergerak, yang sudah ada maupun yang akan ada menjadi jaminan atas seluruh perikatannya dengan kreditor. Apabila terjadi wanprestasi maka seluruh harta benda debitor dijual 
lelang dan dibagi-bagi rata menurut besar kecilnya piutang masing-masing kreditor.

Perlindungan kreditor yang hanya mengandalkan adanya jaminan umum tersebut dirasakan belum memberikan rasa aman bagi kreditor, sehingga dalam praktiknya, penyaluran kredit baik itu berjumlah kecil maupun besar, pihak reditor (biasanya dan terutama adalah bank) memandang perlu untuk meminta diikatnya suatu jaminan khusus sebagai wujud dari prinsip kehati-hatiannya. Bilamana pihak kreditor adalah bank, maka ketentuan ini tercermin dalam Pasal 8 UndangUndang Nomor 10 Tahun 1998 Tentang Perubahan Undang-Undang Nomor 7 Tahun 1992 Tentang Perbankan (selanjutnya disebut UU Perbankan), yang mana ditegaskan dalam pasal tersebut bahwa dalam menyalurkan kredit, bank wajib mempunyai keyakinan berdasarkan analisis yang mendalam atas itikad dan kemampuan serta kesanggupan debitor mengembalikan hutang (kredit) sebagaimana yang dijanjikan. Sedangkan bilamana kreditor itu adalah pihak nonbank, maka jaminan khusus ini tercermin hanya dari Pasal 1132 BW.

Jaminan kebendaan mempunyai posisi paling dominan dan dianggap strategis dalam penyaluran kredit bank. Jaminan kebendaan yang paling banyak diminta oleh bank adalah berupa tanah, karena secara ekonomis tanah mempunyai prospek yang menguntungkan. Bilamana tanah akan dijadikan obyek jaminan, maka aturannya bertumpu pada Undang-Undang No. 5 Tahun 1960 tentang Peraturan Dasar Pokok-Pokok Agraria (selanjutnya disebut UU No. 5/1960) yang mana kemudian atas amanah dari UU No. 5/1960 tersebut lahirlah UndangUndang No. 4 Tahun 1996 tentang Hak Tanggungan Atas Tanah Beserta BendaBenda Yang Berkaitan Dengan Tanah (Selanjutnya disebut dengan UU No. 4/1996), Hak Tanggungan inilah yang kini dijadikan lembaga jaminan untuk tanah, Hak Tanggungan sebagai lembaga jaminan untuk tanah ini juga dijabarkan dalam Pasal 1 ayat (1) UU No. 4/1996, yang mana mengatakan bahwa:

Hak Tanggungan adalah hak jaminan yang dibebankan pada hak atas tanah sebagaimana dimaksud dalam UUPA, berikut atau tidak berikut bendabenda lain yang merupakan satu kesatuan dengan tanah itu, untuk pelunasan utang tertentu, yang memberikan kedudukan yang diutamakan kepada kreditor tertentu terhadap kreditor-kreditor yang lain. 
Berdasarkan definisi Hak Tanggungan yang dijabarkan dalam Pasal 1 ayat (1) UU No. 4/1996 tersebut, dapat diketahui bahwa Hak Tanggungan memberikan kedudukan yang diutamakan kepada kreditor tertentu terhadap kreditor-kreditor lainnya. Yang dimaksud dengan kreditor tertentu adalah yang memperoleh atau yang menjadi pemegang Hak Tanggungan tersebut.

Ketentuan Angka 4 Penjelasan Umum UU No. 4/1996 dijelaskan bahwa yang dimaksud dengan memberikan kedudukan diutamakan kepada kreditor tertentu terhadap kreditor-kreditor lainnya yaitu:

Bahwa jika debitor cidera janji, kreditor pemegang Hak Tanggungan berhak menjual melalui pelelangan umum tanah yang dijadikan jaminan menurut ketentuan peraturan perundang-undangan yang bersangkutan, dengan hak mendahulu daripada kreditor-kreditor yang lain. Kedudukan yang diutamakan tersebut sudah barang tentu tidak mengurangi preferensi piutang-piutang negara menurut ketentuan-ketentuan hukum yang berlaku.

Klausula Pasal 1 dan angka 4 penjelasan umum diatas ini menunjukkan salah satu sifat hak kebendaan, yaitu sifat preferensi (droit de preference) lembaga jaminan Hak Tanggunan, yaitu adanya sifat didahulukan pelunasan piutangnya daripada kreditor lain (kreditor konkuren).

Ketentuan dalam Pasal 4 ayat (4) UU No. 4/1996 menegaskan bahwa Hak Tanggungan dapat dibebankan bukan saja pada hak atas tanah yang menjadi obyek Hak Tanggungan, tetapi juga berikut bangunan, tanaman dan hasil karya yang merupakan satu kesatuan dengan tanah tersebut. Bangunan, tanaman dan hasil karya yang merupakan satu kesatuan dengan tanah tersebut adalah yang dimaksudkan dalam UU No. 4/1996 sebagai benda-benda yang berkaitan dengan tanah. Benda-benda yang berkaitan dengan tanah ini, yang dapat dibebani Hak Tanggungan, tidak terbatas pada benda-benda yang merupakan milik pemegang hak atas tanah yang bersangkutan, namun juga termasuk yang bukan dimiliki oleh pemegang hak atas tanah yang bersangkutan tersebut, sebagaimana diatur dalam Pasal 4 ayat (5) UU No. 4/1996.

Berdasarkan beberapa ketentuan diatas, maka unsur-unsur pokok Hak Tanggungan tersebut adalah:

1. Hak Tanggungan adalah hak jaminan untuk pelunasan hutang 
2. Obyek Hak Tanggungan adalah hak atas tanah sesuai UU No. 5/1960

3. Hak Tanggungan dapat dibebankan atas tanahnya (hak atas tanah) saja, tetapi dapat pula dibebankan berikut benda-benda lain yang merupakan satu-kesatuan dengan tanah itu.

4. Hutang yang dijamin haruslah suatu hutang tertentu.

5. Hak Tanggungan memberikan kedudukan yang diutamakan kepada kreditor tertentu terhadap kreditor lain.

Mengenai hapusnya Hak Tanggungan, dalam UU No. 4/1996 diatur dalam Pasal 18, dalam Pasal 18 ayat (1) UU No. 4/1996 diatur mengenai hapusnya Hak Tanggungan bila:

a. Hapusnya hutang yang dijamin dengan Hak Tanggungan

b. Dilepaskannya Hak Tanggungan oleh pemegang Hak Tanggungan

c. Pembersihan Hak Tanggungan berdasarkan penetapan peringkat oleh Ketua Pengadilan Negeri

d. Hapusnya hak atas tanah yang dibebani dengan Hak Tanggungan

Berdasarkan Pasal 18 ayat (1) huruf (d) diatas, diatur mengenai hapusnya Hak Tanggungan bilamana hak atas tanah yang dibebani Hak Tanggungan itu hapus. Tanah sebagai obyek jaminan Hak Tanggungan yang mana merupakan benda terdaftar, diatasnya dapat dibebani tidak hanya Hak Milik karena sifatnya yang bisa dibebani lebih dari satu macam hak, dan karenanya itu dinamakan hak atas tanah. Dalam pasal ayat (1), (2) dan (3) UU No. 4/1996 disebutkan bahwa hak atas tanah yang dapat dibebani Hak Tanggungan antara lain:

1. Hak Milik

2. Hak Guna Usaha

3. Hak Guna Bangunan

4. Hak Pakai atas Tanah Negara

5. Hak Pakai dan Hak Milik (diatur dalam PP)

Maka berdasarkan ketentuan diatas, bilamana salah satu hak tersebut hilang pada saat masih berlakunya Hak Tanggungan, maka Hak Tanggungan menjadi hapus.

Hilangnya atau hapusnya hak atas tanah bisa disebabkan karena beberapa hal, baik itu wujud tanahnya yang hilang seperti tanah tersebut tertimbun total oleh tanah lain sebagai akibat bencana letusan gunung berapi atau tertutup air bah atau tsunami, atau bahkan hilang karena perbuatan yang disengaja seperti 
penutupan desa untuk pembuatan waduk. Hilangnya tanah seperti ini sudah jarang terajdi dan walaupun terjadi maka antisipasi para pihak yang berkepentingan yaitu diwujudkan dalam bentuk diasuransikannya tanah tersebut.

Hapusnya hak atas tanah kerapkali terjadi karena lewatnya waktu untuk mana hak itu diberikan. Hak-hak atas tanah yang mana ada jangka waktunya, selain Hak Milik, yaitu Hak Guna Bangunan, Hak Guna Usaha dan Hak Pakai tentu saja ada jangka waktu berlakunya walaupun wujud tanah itu masih ada. Dengan berakhirnya hak atas tanah yang bersangkutan, maka hak atas tanah itu kembali kepada yang bersangkutan baik itu pemiliknya, atau kembali pada kekuasaan Negara. Apabila hak atas tanah itu hapus, maka tentu saja posisi kreditor disini menjadi dirugikan, karena sudah barang tentu bila hak atas tanah itu hapus, maka hapuslah Hak Tanggungan, dan bila Hak Tanggungan hapus, kedudukan kreditor Hak Tanggungan akan menjadi kreditor konkuren.

Berdasarkan apa yang telah diuraikan tersebut diatas, permasalahan yang dikaji dalam penulisan ini adalah perlindungan kreditor dan tanggung gugat debitor Hak Tanggungan dalam hal hapusnya hak atas tanah yang sedang dijaminkan.

\section{Hak Tanggungan Sebagai Jaminan Hak Kebendaan}

Ketentuan hukum kebendaan atau hukum benda didalam BW, dapat dijumpai dalam Buku II BW yang mengatur mengenai hukum kebendaan. Hal-hal yang diatur dalam Buku II BW itu bila dirinci adalah sebagai berikut: ${ }^{1}$

1. Tentang kebendaan dan cara-cara membedakan benda

2. Tentang hak kebendaan yang memberikan kenikmatan

3. Tentang kewarisan

4. Tentang piutang-piutang yang diistimewakan

5. Tentang hak kebendaan yang memberikan jaminan

Dalam Buku II BW tersebut diatur mengenai pengertian, cara membedakan benda dan hak-hak kebendaan, baik hak kebendaan yang memberikan kenikmatan atau memberikan jaminan.

\footnotetext{
${ }^{1}$ Rachmadi Usman, Hukum Jaminan Keperdataan, Jakarta:Sinar Grafika, 2008, h. 30.
} 
Konstruksi hukum akan adanya hak kebendaan, dapat secara singkat dijelaskan sebagai berikut. Lahirnya perjanjian kredit antara debitor dan kreditor yang mana merupakan perjanjian obligatoir dan hak yang lahir adalah hak pribadi serta tunduk pada Buku III BW. Lalu terhadap perjanjian hutang-piutang tersebut dikuatkanlah posisis krediotrnya dengan disepakatinya perjanjian jaminan, perjanjian jaminan ini adalah perjanjian jaminan kebendaan karena adanya satu benda tertentu yang diikat untuk pelunasan hutang, karena dalam hal ini obyeknya adalah tanah, maka sebagai benda tidak bergerak perjanjian jaminannya jatuh pada perjanjian jaminan Hak Tanggungan, perjanjian jaminan Hak Tanggungan ini merupakan perjanjian kebendaan, dan karena itu tunduk pada Buku II BW, dan kemudian lahirlah hak kebendaan (Zaakelijkerecht).

Pada dasarnya seluruh harta seseorang itu dijadikan jaminan bagi para kreditornya (Pasal 1131 BW), dan pelunasannya akan dilakukan dengan pembagian secara adil menurut besar kecilnya hutang. Dalam Pasal 1133 BW diadakan pengecualian bagi kondisi diatas, bahwa bilamana ada diantara si berpiutang itu yang mempunyai alasan-alasan yang sah untuk didahulukan, maka pembayarannya akan didahulukan. Alasan-alasan yang sah untuk didahulukan inilah yang mana didalamnya ada jaminan hak kebendaan, yang mana merubah kedudukan kreditor yang awalnya konkuren, menjadi kreditor yang diutamakan yaitu kreditor preferen.

Pada dasarnya, perjanjian dapat dibedakan menjadi 2 (dua) macam, yaitu perjanjian pokok dan perjanjian accesoir. Perjanjian pokok adalah perjanjianperjanjian yang untuk adanya mempunyai dasar yang mandiri (welke zdftanding een redden van bestaan recht). Keberadaan jaminan kebendaan ini merupakan perjanjian tambahan (accessoir), yang mana merupakan pendukung perjanjian pendahulunya (perjanjian pokoknya) yang telah disepakati para pihak yang berupa perjanjian hutang piutang, dengan demikian sifat perjanjian tambahan ini yaitu mengikuti atau bergantung pada perjanjian pokoknya. Dikemukakan oleh Sri Soedewi bahwa: ${ }^{2}$

\footnotetext{
${ }^{2}$ Sri Soedewi Masjchoen Sofwan, Hukum Jaminan di Indonesia : Pokok-Pokok Hukum Jaminan dan Jaminan Perorangan, Yogyakarta:Liberty, 1980, h. 37.
} 
Jaminan dikonstruksikan sebagai perjanjian yang bersifat asesoir yaitu senantiasa merupakan perjanjian yang dikaitkan dengan perjanjian pokok, dan mengabdi pada perjanjian pokok.

Dikemukakan hal serupa oleh Mariam Darus Badrulzaman sebagai berikut: ${ }^{3}$

Sifat asesoir sesuai sifat yang melekat pada hukum jaminan. Gadai dan Hipotek. Lahir dan berakhirnya penyerahan Hak Milik bergantung pada hutang pokok.

Hal ini berdasar bahwa pada umumnya diakui bahwa segala sesuatu yang memperoleh dukungan akan menjadi lebih kokoh ketimbang saat sebelumnya ketika tidak ada pendukungnya, maksudnya perjanjian utang piutang kedudukannya akan semakin kokoh manakala didukung oleh perjanjian jaminan teutama adanya perjanjian kebendaan. Begitu pula bilamana perjanjian obligatoir termasuk perjanjian kredit yang bermula sekedar memiliki sifat relatif sehingga kreditornya hanya bersifat kreditor konkuren, bilamana kemudian didukung oleh perjanjian jaminan yang memiliki sifat kebendaan, mengakibatkan kreditor yang bersangkutan berubah posisi menjadi kreditor preferen dengan hak-hak yang lebih istimewa.

Jaminan hak tangungan ini termasuk dalam jaminan kebendaan, hal ini karena jaminan Hak Tanggungan lahir dari perjanjian yang bersifat accessoir, sebagaimana ditegaskan pula oleh Sutan Remy, bahwa: ${ }^{4}$

Perjanjian Hak Tanggungan bukan merupakan perjanjian yang berdiri sendiri. Keberadaannnya adalah karena adanya perjanjian lain yang disebut perjanjian induk. Perjanjian induk bagi perjanjian Hak Tanggungan adalah perjanjian hutang piutang yang menimbulkan hutang yang dijamin, dengan kata lain perjanjian Hak Tanggungan adalah perjanjian accesoir, dan merupakan perjanjian jaminan kebendaan.

Dalam butir 8 Penjelasan Umum UU No. 4/1996 ditegaskan bahwa:

Oleh karena Hak Tanggungan menurut sifatnya merupakan ikutan atau accessoir pada suatu piutang tertentu, yang didasarkan pada suatu perjanjian utang piutang atau perjanjian lain, maka kelahiran dan keberadaannya ditentukan oleh adanya piutang yang dijamin pelunasannya.

\footnotetext{
${ }^{3}$ Mariam Darus Badrulzaman, Bab-Bab Tentang Credietverband, Gadai, Fidusia, Bandung:Alumni, 1987, h. 95-96.

${ }^{4}$ Sutan Remy Sjahdeini, Hak Tanggungan - Asas-Asas, Ketentuan Pokok dan Masalah Yang Dihadapi Oleh Perbankan, Bandung:Alumni, 1999, h. 29.
} 
Sifat accesoir dari perjanjian Hak Tanggungan juga ditegaskan dalam Pasal 10 ayat (1) dan Pasal 18 ayat (1) UU No. 4/1996 yang menyebutkan bahwa:

1. Pasal 10 ayat (1) UU No. 4/1996 menentukan bahwa perjanjian untuk memberikan Hak Tanggungan merupakan bagian tak terpisahkan dari perjanjian utang piutang yang bersangkutan.

2. Pasal 18 ayat (1) huruf (a) menentukan Hak Tanggungan hapus karena hapusnya utang yang dijamin dengan Hak Tanggungan.

Dengan demikian, maka bilamana para pihak membuat perjanjian gadai, maka lahirlah hak gadai bagi kreditornya, bilamana para pihak membuat perjanjian Hipotek maka lahirlah hak Hipotek, begitu juga bila para pihak membuat perjanjian jaminan Hak Tanggungan, maka lahirlah Hak Tanggungan. Hak semacam ini bersifat sebagai kebendaan, karena lahir bukan dari perjanjian obligatoir Buku II BW, tetapi lahir dari perjanjian kebendaan. Karena Hak Tanggungan lahir dari perjanjian dan berkedudukan sebagai hak kebendaan, maka melekat juga sifat-sifat istimewa yang umumnya ada pada hak kebendaan. Sifatsifat istimewa tersebut sekaligus menjadi penanda atau pembeda untuk hak kebendaan terhadap hak perorangan, sifat-sifat istimewa yang pada umumnya ada dalam hak kebendaan itu antara lain yaitu absolut/mutlak, adanya droit de preference, adanya droit de suite, adanya asas spesialitas dan juga publisitas.

\section{Prinsip Absolut/Mutlak Hak Tanggungan}

Mengenai sifat absolut dari hak kebendaan, Sri Soedewi menyatakan bahwa:

Dimaksud hak kebendaan (zakelijkrecht), yaitu hak mutlak atas sesuatu benda, dimana hak itu memberikan kekuasaan langsung atas sesuatu benda, dan dapat dipertahankan kepada siapapun juga. Hak kebendaan adalah absolut, artinya hak ini dapat dipertahankan terhadap setiap orang. Pemegang hak itu berhak menuntut setiap orang yang mengganggu hak nya itu. ${ }^{5}$

Berkenaan dengan Hak Tanggungan ini, dalam UU No. 4/1996 sifat hak kebendaan secara implisit disebutkan dalam Pasal 1 ayat (1) UU No. 4/1996, yang mana menyebutkan bahwa:

\footnotetext{
${ }^{5}$ Sri Soedewi Machsoen Sofwan, Hukum Benda, Yogyakarta:Liberty, 1981, h. 24.
} 
Hak Tanggungan atas tanah beserta benda-benda yang berkaitan dengan tanah, yang selanjutnya disebut Hak Tanggungan adalah hak jaminan yang dibebankan pada hak atas tanah sebagaimana dimaksud dalam UU No. 5/1960 tentang Peraturan Dasar Pokok-Pokok Agraria, berikut atau tidak berikut benda-benda lain yang merupakan satu kesatuan dengan tanah itu, tuk pelunasan utang tertentu, yang memberikan kedudukan yang diutamakan kepada kreditor tertentu terhadap kreditor lain.

Dalam ketentuan Pasal 1 UU No. 4/1996 tersebut tidak secara jelas disebutkan bahwa Hak Tangungan merupakan Hak Kebendaan dan mempunyai sifat absolut, oleh karena itu Sudargo Gautama mengungkapkan bahwa:

Sifat hak kebendaan itu ada karena pemilik hak-hak tersebut memiliki wewenang untuk mengalihkan atau mengasingkan obyek nya. ${ }^{6}$

Senada dengan pendapat Sudargo Gautama, Mariam Darus Badrulzaman menambahkan bahwa:

UU No. 5/1960 mengenal hak kebendaan bukan hanya pemilik mempunyai wewenang untuk mengalihkan atau mengasingkan, tetapi juga karena hakhak itu tunduk pada pendaftaran. Lembaga pendaftaran inilah yang menjadi ukuran bagi lahirnya hak kebendaan. Pendaftaran tanah dalam UU No. 5/1960 menunjukkan sifat kebendaan itu merupakan bawaan lahir dari UU No. 5/1960 dan bukan merupakan sifat yang diberikan. Hal ini berdasarkan Pasal 528 BW, karena itulah Hak Tanggungan dapat dikatakan mempunyai sifat hak kebendaan, karena ciri-ciri / sifat hak kebendaan pada Hak Tanggungan memang sengaja diberikan oleh pembentuk UU No. 4/1996. Oleh karenanya UU No. 4/1996 merupakan Hak kebendaan, maka mempunyai sifat yang absolut. ${ }^{7}$

Untuk itulah maka dalam lembaga penjaminan Hak Tanggungan ini melekat sifat absolut/mutlak yang mana merupakan sifat dari hak kebendaan.

\section{Prinsip Droit de Suite Hak Tanggungan}

Droit de suite atau zaaksgevolg merupakan sifat hak kebendaan, namun dalam UU No. 5/1960 sebagai landasan lahirnya UU No. 4/1996 tidak secara tegas menyebutkan adanya hak kebendaan. Dalam hak kebendaan ini berarti bahwa hak kebendaan itu bersifat hak itu terus mengikuti bendanya dimanapun

\footnotetext{
6 Sudargo Gautama (Gauw Giok Siong), Tafsiran Undang-Undang Pokok Agraria, Jakarta:Keng Po, 1963, h. 27.

${ }^{7}$ Mariam Darus Badrulzaman, Bab-Bab Tentang Hypotheek, Bandung:Citra Aditya Bakti, 1991, h. 19.
} 
juga (dalam tangan siapapun juga) barang itu berada. Hak ini terus saja mengikuti orang yang mempunyainya. ${ }^{8}$ Dalam Hak Tanggungan, hal ini diatur jelas dalam UU No. 4/1996 yang mana tampak jelas pada Pasal 7 UU No. 4/1996 yang menyatakan bahwa Hak Tanggungan itu tetap mengikuti obyeknya dalam tangan siapapun obyek tersebut berada.

Oleh karena itu, walaupun obyek Hak Tanggungan itu sudah berpindah tangan dan menjadi Hak Milik orang lain, namun Hak Tanggungan itu selalu mengikuti di dalam tangan siapapun obyek Hak Tanggungan berpindah, yang berarti prinsip droit de suite tersebut terdapat dalam UU No. $4 / 1996 .{ }^{9}$

\section{Prinsip Droit de Preference Hak Tanggungan}

Dalam BW, bentuk perlindungan istimewa kian diberikan kepada pemegang jaminan hak kebendaan, pemberian ini berdasar pada Pasal $1133 \mathrm{BW}$, yang menyatakan bahwa hak untuk didahulukan diantara para kreditor itu timbul dari Hak Istimewa, Gadai dan Hipotek. Dalam perkembangan hukum di Indonesia, perlindungan istimewa itu juga berlaku bagi Hak Tanggungan (UU No. 4/1996) dan Fidusia (UU No. 42/1999). ${ }^{10}$

Dalam UU No. 4/1996 tentang kedudukan yang diutamakan kepada kreditor tertentu terhadap kreditor-kreditor lain, semula ditentukan pada Pasal 1 ayat (1) UU No. 4/1996, yang mana menyebutkan bahwa "Hak Tanggungan adalah hak jaminan yang dibebankan pada hak atas tanah yang memberikan kedudukan diutamakan kepada kreditor tertentu terhadap kreditor lainnya." Penjabaran lebih lanjut terdapat dalam Penjelasan Umum Angka (4) Alinea (2) UU No. 4/1996 yang menjelaskan bahwa:

Hak Tanggungan adalah hak jaminan atas tanah untuk pelunasan hutang tertentu, yang memberikan kedudukan diutamakan kepada kreditor tertentu terhadap kreditor-kreditor lain. Dalam arti, bahwa jika debitor cidera janji, kreditor pemegang Hak Tanggungan berhak menjual melalui pelelangan umum tanah yang dijadikan jaminan menurut ketentuan peraturan

${ }^{8}$ Sri Soedewi Machsoen Sofwan, Hukum Perdata: Hukum Benda, Yogyakarta:Liberty, 1974 , h. 25.

9 Herowati Poesoko, Dinamika Hukum Parate Eksekusi Obyek Hak Tanggungan, Yogyakarta:Aswaja Pressindo, 2012, h. 72.

${ }^{10}$ Ibid. 
perundang-undangan yang bersangkutan, dengan hak mendahulu daripada kreditor-kreditor yang lain. Kedudukan diutamakan tersebut sudah barang tentu tidak mengurangi preferensi piutang-piutang Negara menurut ketentuan-ketentuan hukum yang berlaku.

Adanya prinsip droit de preference dalam UU No. 4/1996 ini sudah barang tentu sangatlah menguntungkan bagi kreditor pemegang Hak Tanggungan dalam hak pelunasan hutang.

\section{Prinsip Spesialitas Hak Tangungan}

Prinsip spesialitas ini menentukan bahwa pembebanan suatu obyek jaminan itu haruslah ditentukan secara spesifik obyeknya. Dalam Hak Tanggungan, asas ini tercermin dari Pasal 1174 BW yang mengatur asas spesialitas untuk lembaga jaminan Hipotek, hal ini dikarenakan Hak Tanggungan merupakan transformasi dari lembaga jaminan Hipotek. Dalam ketentuan UU No. 4/1996, asas ini jelas ditentukan dalam Pasal 11 ayat (1) huruf (e) UU No. 4/1996, yang mana menentukan bahwa "di dalam Akta Pemberian Hak Tanggungan wajib dicantumkan uraian yang jelas mengenai obyek Hak Tanggungan". Kata-kata uraian yang jelas mengenai obyek Hak Tanggungan dalam Pasal 11 ayat (1) huruf (e) tersebut menunjukkan bahwa obyek Hak Tanggungan harus secara spesifik dapat ditunjukkan dalam Akta Pemberian Hak Tanggungan yang bersangkutan. Dan oleh karenanya, dalam Hak Tanggungan ini berarti juga terdapat sifat hak kebendaan pada umumnya yaitu adanya asas spesialitas. Hal adanya asas spesialitas dalam Hak Tanggungan ini juga dimaksudkan agar pada saat adanya eksekusi nantinya, pelaksanaan eksekusi oleh eksekutor itu tidaklah pada obyek jaminan yang salah.

\section{Prinsip Publisitas Hak Tanggungan}

Seperti halnya asas spesialitas dalam Hak Tanggungan, asas publisitas ini pun juga merupakan asas dalam lembaga jaminan Hipotek pada awal mulanya, asas ini juga diberlakukan pada Hak Tanggungan karena Hak Tanggungan merupakan transformasi dari lembaga jaminan Hipotek yang pada awal mulanya 
merupakan lembaga jaminan untuk obyek tanah. Asas ini berada dalam Pasal 1179 BW yang mana menurut Pasal tersebut, pembukuan Hipotek harus dilakukan dalam regiter-register umum yang memang khusus disediakan untuk itu. Jika pembukuan demikian tidak dilakukan maka Hipotek yang bersangkutan tidak mempunyai kekuatan apapun, bahka. Pula terhadap orang-orang yang berpiutang yang tidak mempunyai kekuatan Hipotek. ${ }^{11}$

Dari pasal diatas, menentukan bahwa hak jaminan baru lahir ketika dilakukan pendaftaran dakam register umum, yang mana sebenarnya saat pendaftaran itu dilakukan, itu juga mengikat pihak ketiga yang tidak memiliki hubungan apa-apa dengan jaminan Hipotek yang bersangkutan, agar menghormati jaminan Hipotek tersebut dan waspada bila ingin mengadakan suatu perbuatan hukum terhadap obyek jaminan tersebut. Dengan demikian wujud dari asas publisitas ini adalah melalui pendaftaran.

Dalam ketentuan Hak Tanggungan, dalam UU No. 4/1996, asas publisitas ini ditentukan dalam Pasal 13 UUHT yang menyatakan bahwa "Pemberian Hak Tanggungan wajib didaftarkan pada kantor pertanahan". Dalam Penjelasan Pasal 13 ayat (1) UU No. 4/1996 disebutkan bahwa "Pendaftaran pemberian Hak Tanggungan merupakan syarat mutlak untuk lahirnya Hak Tanggungan dan mengikatnya Hak Tanggungan terhadap pihak ketiga". Terkait dengan asas publisitas Hak Tanggungan ini, Herowati Poesoko menjabarkan bahwa:

Tidak adil bagi pihak ketiga untuk terkait dengan pembebanan suatu Hak Tanggungan atas suatu obyek Hak Tanggungan apabila pihak ketiga tidak dimungkinkan untuk mengetahui tentang pembebanan Hak Tanggungan itu. Hanya dengan cara pencatatan atau pendaftaran yang terbuka untuk umum lah yang memungkinkan pihak ketiga dalat mengetahui tentang adanya pembebanan Hak Tanggungan atas suatu hak atas tanah. ${ }^{12}$

Dari kelima sifat umum hak kebendaan tersebut, semakin menunjukkan bahwa Hak Tanggungan merupakan jaminan hak kebendaan yang lahir dari perjanjian, dan memberikan perlindungan yang cukup komprehensif kepada krediturnya dalam hal pelunasan hutang.

\footnotetext{
${ }^{11}$ Ibid, h. 80 .

${ }^{12}$ Ibid.
} 


\section{Hilangnya Hak Atas Tanah Yang Dijadikan Jaminan \\ Obyek Jaminan Hak Tanggungan}

Untuk suatu hak atas tanah dapat dijadikan jaminan hutang dengan Hak Tanggungan, menurut Boedi Harsono, suatu benda itu haruslah memenuhi syarat yang tersirat juga tersurat dalam UU No. 4/1996, yaitu: ${ }^{13}$

1. Dapat dinilau dengan yabf, karena hutang yang dijamin berupa uang;

2. Termasuk hak yang didaftar dalam daftar umum, karena harus memenuhi syarat publisitas;

3. Mempunyai sifat dapat dipindahtangankan, karena apabila debitor cidera janji benda yang dijadikan jaminan itu akan dijual dimuka umum; dan

4. Memerlukan penunjukan dengan undang-undang.

Berdasarkan Pasal 4 ayat (1) UU No. 4/1996, hak atas tanah yang dapat dibebani Hak Tanggungan Dalam UU No. 4/1996, hak atas tanah yang dapat dibebani dengan Hak Tanggungan dan sesuai ketentuan Pasal 51 UU No. 4/1996, yaitu :

1. Hak Milik

2. Hak Guna Bangunan

3. Hak Guna Usaha

Lebih lanjut lagi, dalam Pasal 4 ayat (2) UU No. 4/1996 memberikan kesempatan kepada Hak Pakai sebagai obyek Hak Tanggungan, yang mana disebutkan bahwa

Selain hak-hak atas tanah sebagaimana dimaksud pada ayat (1), Hak Pakai atas tanah Negara yang menurut ketentuan yang berlaku itu wajib didaftar dan menurut sifatnya itu dapat dipindahtangankan, dapat juga dibebani Hak Tanggungan.

Ditunjuknya Hak Pakai sebagai salah satu obyek Hak Tanggungan sebenarnya menyimpang dari ketentuan UU No. 5/1960 yang mana menjadi dasar dari UU No. 4/1996. Dalam UU No. 5/1960 hanya disebutkan 3 (tiga) macam hak atas tanah yang dapat dibebani Hak Tanggungan, yaitu Hak Milik, Hak Guna

\footnotetext{
${ }^{13}$ Boedi Harsono, “Konsepsi Pemikiran Tentang Undang-Undang Hak Tanggungan", Seminar UUHT, UNPAD, h. 10.
} 
Bangunan dan Hak Guna Usaha. Hal ini kemudian ditegaskan dalam Penjelasan Umum angka (5) alinea II dan III UU No. 4/1996 sebagai berikut:

Hak Pakai dalam UU No. 5/1960 tidak ditunjuk sebagai obyek Hak Tanggungan, karena pada waktu itu tidak termasuk hak-hak atas tanah yang wajib didaftar dan karenanya tidak dapat memenuhi syarat publisitas untuk dapat dijadikan jaminan utang. Dalam perkembangannya Hak Pakai pun harus didaftarkan, yaitu Hak Pakai yang diberikan atas tanah Negara. Sebagian dari Hak Pakai yang didaftar itu, menurut sifat dan kenyataannya dapat dipindahtangankan, yaitu yang diberikan kepada orang perseorangan dan badan-badan hukum perdata.

Dalam Undang-Undang Nomor 16 Tahun 1985 tentang Rumah Susun, Hak Pakai yang dimaksudkan itu dapat dijadikan jaminan utang dengan dibebani fidusia. Dalam Undang-Undang ini Hak Pakai tersebut ditunjuk sebagai obyek Hak Tanggungan. Sehubungan dengan itu, maka untuk selanjutnya, Hak Tanggungan merupakan satu-satunya lembaga hak jaminan atas tanah, dan dengan demikian menjadi tuntaslah unifikasi Hukum Tanah Nasional, yang merupakan salah satu tujuan utama Undang-Undang Pokok Agraria. Pernyataan bahwa Hak Pakai tersebut dapat dijadikan obyek Hak Tanggungan merupakan penyesuaian ketentuan Undang-Undang Pokok Agraria dengan perkembangan Hak Pakai itu sendiri serta kebutuhan masyarakat.

Selain mewujudkan unifikasi Hukum Tanah Nasional, yang tidak kurang pentingnya adalah, bahwa dengan ditunjuknya Hak Pakai tersebut sebagai obyek Hak Tanggungan, bagi para pemegang haknya, yang sebagian terbesar terdiri atas golongan ekonomii lemah yang tidak berkemampuan untuk mempunyai tanah dengan Hak Milik atau Hak Guna Bangunan, menjadi terbuka kemungkinannya untuk memperoleh kredit yang diperlukannya, dengan menggunakan tanah yang dipunyainya sebagai jaminan.

Untuk Hak Pakai atas tanah Negara dengan peruntukan tertentu, meskipun terdaftar, karena sifatnya yang tidak dapat dipindahtangankan, maka Hak Pakai tersebut tidak dapat dijadikan obyek Hak Tanggungan. Sedangkan untuk Hak Pakai yangn diberikan oleh pemilik tanah berdasarkan ketentuan Pasal 4 ayat (3) UU No. 4/1996 dan Penjelasan Umum diatas, di kemudian hari dapat menjadi obyek Hak Tanggungan (lebih lanjut akan diatur dalam Peraturan Pemerintah). Sedasar dengan penjabaran diatas, maka obyek Hak Tanggungan adalah:

1. Hak Milik;

2. Hak Guna Usaha; 
3. Hak Guna Bangunan;

4. Hak Pakai atas tanah Negara yang menurut sifatnya dapat dipindahtangankan;

5. Hak Pakai atas tanah Hak Milik (masih akan diatur dengan Peraturan Pemerintah).

Mengenai obyek Hak Tanggungan ini, berlaku asas pemisahan horizontal dalam UU No. 4/1996, sedikit berbeda dengan BW yang menganut asas perlekatan, hal ini dikarenakan UU No. 4/1996 lahir dari UU No. 5/1960 yang menganut asas pemisahan horizontal dalam hukum adat. Dalam BW, asas perlekatan ini tersurat dalam Pasal 1165 BW yang mana menentukan bahwa:

Setiap Hipotek meliputi segala perbaikan di kemudian hari pada benda yang dibebani, juga segala apa yang menjadi satu kesatuan dengan benda itu karena pertumbuhan atau pembangunan.

Dari Pasal 1165 BW ini dapat diambil makna bahwa tanpa diperjanjikan terlebih dahulu pun, segala benda yang berkaitan dengan tanah yang sedang dibebani Hipotek, baik benda itu sudah ada atau yang dikemudian hari itu baru akan ada dan berkaitan dengan tanah itu, maka demi hukum juga termasuk obyek Hipotek. Berbeda dengan UU No. 4/1996 yang mana berdasar pada UU No. 5/1960, UUPA berdasar dari hukum adat Indonesia, sedangkan hukum adat itu menganut asas pemisahan horizontal, oleh karena itu segala benda yang merupakan satu kesatuan dengan tanah yang dibebani Hak Tanggungan itu tidak dengan sendirinya terbebani pula dengan Hak Tanggungan yang mana sudah dibebankan kepada tanah tersebut. Penjelasan Umum angka (6) alinea (1) UU No. 4/1996 menjelaskan bahwa:

Sebagai-mana diketahui Hukum Tanah Nasional didasarkan pada hukum adat, yang menggunakan asas pemisahan horizontal. Sehubungan dengan itu, maka dalam kaitannya dengan bangunan, tanaman, dan hasil karya tersebut, Hukum Tanah Nasional menggunakan juga asas pemisahan horizontal. Dalam rangka asas pemisahan horizontal, benda-benda yang merupakan satu kesatuan dengan tanah menurut hukum bukan merupakan bagian dari tanah yang bersangkutan. Oleh karena itu setiap perbuatan hukum mengenai hak-hak atas tanah, tidak dengan sendirinya meliputi benda-benda tersebut. 
Berdasarkan ketentuan diatas, maka dapat diketahui bahwa UU No.4/1996 menganut asas pemisahan horizontal dalam pembebanan Hak Tanggungan. Namun sebenarnya asas tersebut tidaklah mutlak, perkembangan kebutuhan praktik menuntut agar diberikannya jalan kepada obyek yang melekat pada tanah tersebut juga dapat terbebani Hak Tanggungan, hal in kemudian dapat dilakukan dengan membuat kesepakatan antara debitor dan kreditor didalam Akta Pemberian Hak Tanggungan (selanjutnya disebut APHT). Ketentuan ini dalam UU No. 4/1996 ditegaskan dalam Pasal 4 ayat (4) sebagai berikut:

Hak Tanggungan dapat juga dibebankan pada hak atas tanah berikut bangunan, tanaman, dan hasil karya yang telah ada atau akan ada yang merupakan satu kesatuan dengan tanah tersebut, dan yang merupakan milik pemegang hak atas tanah yang pembebanannya dengan tegas dinyatakan di dalam Akta Pemberian Hak Tanggungan yang bersangkutan.

Dijelaskan pula dalam Penjelasan Umum angka (6) alinea (2) UU No. 4/1996 sebagai berikut:

Namun demikian penerapan asas-asas hukum adat tidaklah mutlak, melainkan selalu memperhatikan dan disesuaikan dengan perkembangan kenyataan dan kebutuhan dalam masyarakat yang dihadapi-nya. Atas dasar kenyataan sifat hukum adat itu, dalam rangka asas pemisahan horizontal tersebut, dalam Undang-undang ini dinyatakan, bahwa pembebanan Hak Tanggungan atas tanah, dimungkinkan pula meliputi benda-benda sebagaimana dimaksud di atas. Hal tersebut telah dilakukan dan dibenarkan oleh hukum dalam praktek, sepanjang benda-benda tersebut merupakan satu kesatuan dengan tanah yang bersangkutan dan keikutsertaannya dijadikan jaminan, dengan tegas dinyatakan oleh pihak-pihak dalam Akta Pemberian Hak Tanggungannya. Bangunan, tanaman, dan hasil karya yang ikut dijadikan jaminan itu tidak terbatas pada yang dimiliki oleh pemegang hak atas tanah yang bersangkutan, melainkan dapat juga meliputi yang dimiliki pihak lain. Sedangkan bangunan yang menggunakan ruang bawah tanah, yang secara fisik tidak ada hubungannya dengan bangunan yang ada di atas permukaan bumi di atasnya, tidak termasuk dalam pengaturan ketentuan mengenai Hak Tanggungan menurut Undang-undang ini.

Berdasarkan penjabaran diatas maka diketahui bahwa Hak Tanggungan sebagai hak kebendaan yang mempunyai juga sifat-sifat istimewa hak kebendaan, obyeknya adalah berupa hak atas tanah (Hak Milik, Hak Guna Usaha, Hak Guna Bangunan, Hak Pakai atas Hak Milik, Hak Pakai atas Tanah Negara), dan tidaklah serta-merta membuat apa yang melekat diatas tanah itu juga membuatnya menjadi 
obyek Hak Tanggungan seperti halnya pada Hipotek yang mana pada awal mulanya mengeatur tentang jaminan obyek tanah, namun obyek yang melekat pada hak atas tanah yang dijaminkan itu dapat juga menjadi obyek jaminan Hak Tanggungan bilamana disepakati dalam APHT nya.

\section{Akibat Dari Hilangnya Hak Atas Tanah Yang Sedang Dijaminkan}

Hak Tanggungan yang dijadikan obyek utama adalah hak atas tanah, walaupun dalam praktiknya, sebagaimana Penjelasan Umum UU No. 4/1996 angka (6) ditentukan bahwa dalam kenyataannya seringkali terdapat benda-benda berupa bangunan, tanaman dan hasil karya yang secara tetap merupakan satu kesatuan dengan tanah yang dijadikan jaminan tersebut. Menurut Muhammad Djumhana, Hak Tanggungan mempunyai karakteristik dengan ciri-ciri diantaranya yaitu: ${ }^{14}$

1. Tidak dapat dibagi-bagi kecuali diperjanjikan lain. Maksudnya bahwa Hak Tanggungan membebani secara utuh obyek Hak Tanggungan dan setiap bagian darinya, artinya dengan telah dilunasinya sebagian dari hutang yang dijamin itu tidak berarti terbebasnya sebagian obyek Hak Tanggungan dari beban Hak Tanggungan, melainkan Hak Tanggungan itu tetap membebani seluruh obyek Hak Tanggungan untuk sisa hutang yang belum dilunasi. (Pasal 2 ayat (1) UU No. 4/1996), namun demikian dapat disimpangi artinya Hak Tanggungan itu dapat hanya membebani sisa obyek Hak Tanggungan untuk menjamin sisa hutang yang belum dilunasi apabila diperjanjikan lain (Pasal 2 ayat (2) UU No. 4/1996);

2. Tetap mengikuti obyeknya dalam tangan siapapun obyek tersebut berada (droit de suite), maksudnya walaupun obyek Hak Tanggungan sudah berpindah tangan dan menjadi milik pihak lain, kreditor masih tetap dapat menggunakan haknya melakukan eksekusi jika debitor wanprestasi (Pasal 7 UU No. 4/1996);

3. Accesoir, artinya merupakan ikutan dari perjanjian pokok, maksudnya bahwa perjanjian Hak Tanggungan tersebut ada apabila telah ada perjanjian pokoknya yang berupa perjanjian yang ditimbulkan hubungan hukum hutang piutang, sehingga akan hapus dengan hapusnya perjanjian pokoknya (Pasal 10 ayat (1) UU No. 4/1996).

4. Asas spesialitas, yaitu bahwa unsur-unsur Hak Tanggungan tersebut wajib ada untuk sahnya APHT, misalnya mengenai obyek hutang yang dijamin (Pasal 11 ayat (1) UU No. 4/1996), dan apabila tidak

${ }^{14}$ Muhammad Djumhana, Hukum Perbankan di Indonesia, Bandung:Citra Aditya Bakti, , 2000, h. 411-412. 
dicantumkan maka mengakibatkan akta yang bersangkutan batal demi hukum;

5. Asas publisitas, yaitu perlunya perbuatan yang berkaitan dengan Hak Tanggungan ini diketahui pula oleh pihak ketiga, dan salah satu realisasinya yaitu dengan didaftarkannya pemberian Hak Tanggungan tersebut, hal ini merupakan syarat mutlak untuk lahirnya Hak Tanggungan tersebut dan mengikatnya Hak Tanggungan terhadap pihak ketiga (Pasal 13 ayat (1) UU No. 4/1996).

Berkaitan dengan hilangnya hak atas tanah, maka berkaitan pula dengan hapusnya Hak Tanggungan. Hapusnya hak tangungan diatur dalam Pasal 18 UU No. 4/1996, ayat (1) dari pasal tersebut menegaskan bahwa:

Hak Tanggungan hapus karena hal-hal sebagai berikut:

1. Hapusnya utang yang dijamin dengan Hak Tanggungan;

2. Dilepaskannya Hak Tanggungan oleh pemegang Hak Tanggungan;

3. Pembersihan Hak Tanggungan berdasarkan penetapan peringkat oleh Ketua Pengadilan Negeri;

4. Hapusnya hak atas tanah yang dibebani Hak Tanggungan.

Terlihat dari Pasal 18 ayat (1) angka (4) UU No. 4/1996 tersebut, bahwa Hak Tanggungan juga menjadi hapus bilamana hak atas tanah yang dibebani Hak Tanggungan itu juga hapus, hal ini cukup dapat dimengerti karena berdasarkan uraian sebelumnya dapat diketahui bahwa Hak Tanggungan adalah hak kebendaan, bilamana obyek hak kebendaan itu hilang maka jaminan hak kebendaan itupun tidak ada artinya lagi. Hapusnya hak atas tanah kerapkali terjadi karena lewatnya waktu, untuk mana hak itu diberikan. Hak-hak yang lebih rendah tingkatannya daripada Hak Milik seperti Hak Guna Bangunan atau Hak Guna Usaha dan Hak Pakai, tentu saja terbatas masa waktu berlakunya, sekalipun fisik tanah tersebut masih nyata ada. Dengan berakhirnya hak atas tanah yang bersangkutan, maka hak atas tanah yang bersangkutan itu kembali kepada pemiliknya dan kalau hak tersebut diberikan oleh Negara maka tanah tersbeut kembali kepada kekuasaan Negara.

Hapusnya pembebanan hak atas tanah meskipun seripikat Hak Tanggungan diterbitkan oleh Badan Pertanahan Nasional (selanjutnya disebut BPN) sebagai badan atau pejabat Tata Usaha Negara, jika sertifikat hak atas tanah itu dibatalkan atas putusan Pengadilan Tata Usaha Negara, sertifikat Hak Tanggungan tidak 
perlu dimohonkan pembatalan, melainkan akan batal dengan sendirinya. Hal ini berarti bahwa dengan dibatalkannya sertifikat hak atas tanah, maka sertifikat Hak Tanggungan menjadi batal dengan sendirinya, dengan kata lain tidak perlu pula dimohonkan pasa Pengadilan Tata Usaha Negara, melainkan batal dengan sendirinya atau cukup dimohonkan pembatalan pada BPN. Dalam Penjelasan Pasal 18 UUHT alinea (1) dan (2) ditegaskan bahwa:

Sesuai dengan sifat accessoir dari Hak Tanggungan, adanya Hak Tanggungan tergantung pada adanya piutang yang dijamin pelunasannya. Apabila piutang itu hapus karena pelunasan atau sebab-sebab lain, dengan sendirinya Hak Tanggungan yang bersangkutan menjadi hapus juga.

Selain itu, pemegang Hak Tanggungan dapat melepaskan Hak Tanggungannya dan hak atas tanah dapat hapus yang mengakibatkan hapusnya Hak Tanggungan.

Berdasarkan uraian ini, meskipun Hak Tanggungan memiliki sifat-sifat istimewa hak kebendaan yang telah disebutkan sebelumnya, bilamana hak atas tanah itu hapus, maka berakhirlah Hak Tanggungan yang akan diikuti berubahnya status kreditor preferen menjadi kreditor konkuren. Hal ini membawa kreditor pada posisi yang rawan akan perlindungan yang komprehensif. Keadaan yang dapat membawa kreditor dalam keadaan yang cukup rawan ini ternyata difasilitas oleh pembentuk Undang-Undang juga, awal mula fasilitas perlindungan kreditor atas hilangnya hak atas tanah ini terlihat dalam Penjelasan Pasal 18 UU No. 4/1996 alinea (3) yang menegaskan bahwa:

Hak atas tanah dapat hapus antara lain karena hal-hal sebagaimana disebut dalam Pasal 27, Pasal 34, dan Pasal 40 Undang-Undang Nomor 5 Tahun 1960 tentang Peraturan Dasar Pokok-Pokok Agraria atau peraturan perundang-undangan lainnya. Dalam hal Hak Guna Usaha, Hak Guna Bangunan, atau Hak Pakai yang dijadikan obyek Hak Tanggungan berakhir jangka waktu berlakunya dan diperpanjang berdasarkan permohonan yang diajukan sebelum berakhirnya jangka waktu tersebut, Hak Tanggungan dimaksud tetap melekat pada hak atas tanah yang bersangkutan.

Ketentuan diatas memberikan jalan bagi kreditor untuk dapat melakukan upaya hukum penangkal resiko agar hak atas tanah tersebut tidak hilang sehingga tetap melekat sebagai obyek Hak Tanggungan yang bersangkutan. Untuk itu kreditor perlu melakukan upaya hukum sebagai perwujudan nyata dari kesempatan yang 
diberikan oleh Penjelasan Pasal 18 UU No. 4/1996 tersebut guna melindungi posisinya dan hak nya dalam hal pelunasan hutang. Perihal upaya perlindungan kreditor ini akan dibahas lebih lanjut dalam sub-bab berikutnya.

\section{Batas Waktu Hak Atas Tanah}

Berdasarkan uraian sebelumnya, telah disebutkan bahwa dalam praktik yang sering terjadi hilangnya hak atas tanah adalah karena lewatnya waktu, cukup jarang terjadi hapusnya hak atas tanah yang dikarenakan hilangnya fisik tanah yang bersangkutan karena bencana alam, oleh karenanya berbagai hak atas tanah yang dapat dijadikan obyek Hak Tanggungan perlu untuk dijelaskan secara singkat pula karakter akan batas waktunya.

\section{Batas Waktu Hak Milik}

Hak milik atas tanah dapat dipunyai oleh perseorangan Warga Negara Indonesia dan badan-badan hukum yang ditunjuk oleh Pemerintah ${ }^{15}$. Karena belum ada Undang-Undang yang mengatur secara khusus mengenai Hak Milik, maka ketentuan mengenai Hak Milik masih bersumber pada UU No. 5/1960, yaitu pada Pasal 16 ayat (1) huruf (a) UU No. 5/1960, dan secara khusus diatur dalam Pasal 20 sampai dengan 27 UU No. 5/1960. Berdasarkan Pasal 20 UU No. 5/1960 disebutkan bahwa "Hak Milik adalah hak turun-temurun, terkuat, dan terpenuh yang dapat dipunyai seseorang atas tanah dengan mengingat ketentuan dalam Pasal 6 UU No. 5/1960". Dalam Penjelasan Pasal 20 UU No. 5/1960 tersebut ditegaskan bahwa Hak Milik tidak mempunyai batas waktu tertentu, mudah dipertahankan dari gangguan pihak lain, dan tidak mudah hapus dan dapat memberikan kewenangan paling luas pada pemiliknya dibanding hak atas tanah yang lain.

\section{Batas Waktu Hak Guna Usaha}

\footnotetext{
15 Pasal 21 Undang-Undang Nomor 5 Tahun 1960 tentang Peraturan Dasar Pokok-Pokok Agraria (Lembaran Negara Republik Indonesia Tahun 1960 Nomor 104, Tambahan Lembaran Negara Republik Indonesia Nomor 2043).
} 
Pada dasarnya ketentuan mengenai Hak Guna Usaha (HGU) ini disebutkan dalam Pasal 16 ayat (1) huruf (b) UU No. 5/1960, khususnya dalam Pasal 28 sampai dengan Pasal 34 UU No. 5/1960. Peraturan lebih lanjut sesuai amanah Pasal 50 ayat (2) UU No. 5/1960 yaitu Peraturan Pemerintah No. 40 Tahun 1996 tentang Hak Guna Usaha, Hak Guna Bangunan dan Hak Pakai atas Tanah (PP No. 40/1996). Pasal 8 jo Pasal 10 PP No. 40/1996 mengatur mengenai jangka waktu HGU yaitu jangka waktu Hak Guna Usaha untuk pertama kalinya adalah 35 (tiga puluh lima) tahun, dapat diperpanjang untuk jangka waktu selama 25 (dua puluh lima) tahun, dan dapat diperbaharui untuk jangka waktu 35 (tiga puluh lima) tahun, dan permohonan perpanjangannya paling lambat dua tahun sebelum jangka waktu Hak Guna Usaha tersebut berakhir.

\section{Batas Waktu Hak Guna Bangunan}

Serupa dengan Hak Guna Usaha, sesuai amanah Pasal 50 UU No. 5/1960, Hak Guna Bangunan diatur secara lebih khusus dalam PP No. 40/1996, dalam Pasal 21 PP No. 40/1996 ini ditegaskan bahwa tanah yang dapat diberikan Hak Guna Bangunan adalah: (a). Tanah Negara; (b). Tanah Hak Pengelolaan; (c). Tanah Hak Milik. Oleh karena ketentuan Pasal 21 PP No. 40/1996 tersebut, maka jangka waktu di setiap jenis tanahnya pun relatif berbeda, yaitu pengaturannya ada dalam Pasal 25 jo Pasal 29 PP No. 40/1996 yang menentukan bahwa jangka waktu Hak Guna Bangunan berbeda pada Hak Guna Bangunan yang berada pada tanah Hak Milik. Hak Guna Bangunan atas Tanah Negara dan atas Tanah Pengelolaan berjangka waktu paling lama 30 (tiga puluh) tahun, dapat diperpanjang untuk jangka waktu paling lama 20 (dua puluh) tahun, dan dapat diperbaharui untuk jangka waktu 30 (tiga puluh) tahun. Sedangkan atas Tanah Hak Milik berjangka waktu 30 (tiga puluh) tahun dan tidak ada perpanjangan, bila ingin diperpanjang maka antara pemilik tanah dengan pemilik Hak Guna Bangunan dapat dibuat kesepakatan dengan pemberian Hak Guna Bangunan baru dengan akta yang baru pula yang dibuat oleh Pejabat Pembuat Akta Tanah (PPAT) dan wajib didaftarkan pada Kantor Pertanahan Kabupaten / Kota Setempat. 
Terkait permohonan untuk pembaharuan atau perpanjangan Hak Guna Bangunan, Pasal 27 PP No. 40/1996 mengatur bahwa permohonan perpanjangan jangka waktu Hak Guna Bangunan atau pembaharuannya diajukan selambatlambatnya dua tahun sebelum berakhir-nya jangka waktu Hak Guna Bangunan tersebut atau perpanjangannya.

\section{Batas Waktu Hak Pakai}

Serupa dengan Hak Guna Usaha, sesuai amanah Pasal 50 UUPA, Hak Pakai diatur secara lebih khusus dalam PP No. 40/1996, dalam Pasal 41 PP No. 40/1996 ini ditegaskan bahwa tanah yang dapat diberikan Hak Pakai adalah: (a). Tanah Negara; (b). Tanah Hak Pengelolaan; (c). Tanah Hak Milik. Berdasarkan Pasal 41 ayat (1) UU No. 5/1960 definisi dari Hak Pakai adalah:

Hak pakai adalah hak untuk menggunakan dan/atau memungut hasil dari tanah yang dikuasai langsung oleh Negara atau tanah milik orang lain, yang memberi wewenang dan kewajiban yang ditentukan dalam keputusan pemberiannya oleh pejabat yang berwenang memberikannya atau dalam perjanjian dengan pemilik tanahnya, yang bukan perjanjian sewa-menyewa atau perjanjian pengolahan tanah, segala sesuatu asal tidak bertentangan dengan jiwa dan ketentuan-ketentuan Undang-undang ini.

Mengenai jangka waktu keberlakuan Hak Pakai, karena berbagai hak atas tanah yang dapat dibebani Hak Pakai, maka pengaturannya pun berbeda, dalam Pasal 45 ayat (1) dan (2) jo Pasal 49 PP No. 40/1996 dapat ditarik kesimpulan bahwa Hak Pakai atas Tanah Negara dan Tanah Hak Pengelolaan berjangka waktu pertama kali paling lama 25 (dua puluh lima) tahun, dapat diperpanjang dengan jangka waktu paling lama 20 (dua puluh) tahun, dan dapat diperbaharui dengan jangka waktu paling lama 25 (dua puluh lima) tahun. Berbeda dengan Hak Pakai atas Tanah Hak Milik yang mana diberikan pertama kali untuk jangka waktu 25 (dua puluh lima) tahun namun tidak dapat diperpanjang, untuk memperpanjang yaitu dengan membuat kesepakatan antara pemilik tanah dan pemegang Hak Pakai dengan pembaharuan Hak Pakai baru dengan akta yang dibuat oleh Pejabat Pembuat Akta Tanah (PPAT) dan wajib didaftarkan pada Kantor Pertanahan Kabupaten / Kota setempat untuk dicatat dalam buku tanah. 
Terkait permohonan untuk pembaharuan atau perpanjangan Hak Pakai, Pasal 47 PP No. 40/1996 mengatur bahwa permohonan perpanjangan jangka waktu Hak Pakai atau pembaharuannya diajukan selambat-lambatnya dua tahun sebelum berakhir-nya jangka waktu Hak Pakai tersebut atau perpanjangannya.

\section{Janji-Janji Dalam Akta Pemberian Hak Tanggungan (APHT)}

Berdasarkan UU No. 4/1996, proses pembebanan Hak Tanggungan dilaksanakan melalui 2 (dua) tahap kegiatan, yaitu:

a. Tahap pemberian Hak Tanggungan dengan dibuatnya Akta Pembebanan Hak Tanggungan oleh Pejabat Pembuat Akta Tanah;

b. Tahap pendaftaran Hak Tanggungan oleh Kantor Pertanahan.

Berdasarkan Pasal 10 ayat (2) UU No. 4/1996 menyebutkan bahwa pemberian Hak Tanggungan wajib dilakukan dengan pembuatan Akta Pemberian Hak Tanggungan (selanjutnya disebut APHT) oleh Pejabat Pembuat Akta Tanah (selanjutnya disebut PPAT) sesuai dengan peraturan perundang-undangan yang berlaku. Selanjutnya dalam Penjelasan Umum angka (7) alinea (2) UUHT dijelaskan bahwa:

Menurut peraturan perundang-undangan yang berlaku, PPAT adalah pejabat umum yang berwenang membuat akta pemindahan hak atas tanah dan akta lain dalam rangka pembebanan hak atas tanah, yang bentuk aktanya ditetapkan, sebagai bukti dilakukannya perbuatan hukum tertentu mengenai tanah yang terletak dalam daerah kerjanya masing-masing. Dalam kedudukan sebagai yang disebutkan di atas, maka akta-akta yang dibuat oleh PPAT merupakan akta otentik.

Dinyatakan dalam Pasal 1 angka 1 jo. Pasal 15 ayat (1) Undang-Undang Nomor 30 Tahun 2004 tentang Jabatan Notaris (UU No. 30/2004), mengenai akta otentik, bahwa:

Notaris adalah pejabat yang berwenang membuat akta otentik mengenai semua perbuatan, perjanjian, dan ketetapan yang diharuskan oleh peraturan perundang-undangan dan/atau yang dikehendaki oleh yang berkepentingan untuk dinyatakan dalam akta otentik, menjamin kepastian tanggal pembuatan akta, menyimpan akta, memberikan grosse, salinan dan kutipan akta sepanjang pembuatan akta-akta itu tidak juga ditugaskan atau dikecualikan kepada pejabat lain atau orang lain yang ditetapkan oleh Undang-Undang. 
Meskipun dalam UU No. 30/2004 tegas ditentukan bahwa notaris berwenang membuat akta otentik yang mempunyai kekuatan hukum sempurna, namun demikian akta otentik tidak harus selalu dibuat oleh notaris, karena sesungguhnya akta otentik merupakan suatu akta yang ditentukan oleh Undang-Undang, dibuat oleh pegawai-pegawai umum yang berkuasa atas itu ditempat mana akta dibuatnya. ${ }^{16}$ Habib Adjie menyatakan bahwa,

Tulisan-tulisan otentik berupa akta otentik, yang dibuat dalam bentuk yang sudah ditentukan oleh undang-undang, dibuat di hadapan pejabat-pejabat (pegawai umum) yang diberi wewenang dan di tempat dimana akta tersebut dibuat. ${ }^{17}$

Lebih lanjut lagi juga dijabarkan olehnya bahwasanya akta otentik tidak saja dapat dibuat oleh notaris. ${ }^{18}$ Dengan ini jelas dimungkinkan bahwa akta yang dibuat oleh pejabat selain notaris juga merupakan akta otentik. Lebih lengkapnya, C.A. Kraan juga menyatakan pendapatnya mengenai akta otentik, bahwa akta otentik mempunyai ciri sebagai berikut: ${ }^{19}$

1. Suatu tulisan, dibuat dengan sengaja dibuat semata-mata untuk dijadikan alat bukti atau suatu bukti dari keadaan sebagaimana disebutkan di dalam tulisan dibuat dan dinyatakan oleh pejabat yang berwenang. Tulisan tersebut turut ditandatangani oleh atau hanya ditandatangani oleh pejabat bersangkutan saja.

2. Suatu tulisan sampai ada bukti sebaliknya, dianggap berasal dari pejabat yang berwenang.

3. Ketentuan perundang-undangan yang harus dipenuhi, ketentuan tersebut mengatur tata cara pembuatannya (sekurang-kurangnya memuat ketentuan-ketentuan mengenai tanggal, tempat dibuatnya akta suatu tulisan, nama dan kedudukan atau jabatan pejabat yang membuatnya data dimana dapat diketahui mengenai hal-hal tersebut).

4. Seorang pejabat yang diangkat oleh negara dan mempunyai sifat dan pekerjaan yang mandiri (onafhankelijk-independence) serta tidak memihak (onpatijdigheid-impartiality) dalam menjalankan jabatannya.

5. Pernyataan dari fakta atau tindakan yang disebutkan oleh pejabat adalah hubungan hukum di bidang hukum privat.

${ }^{16}$ Pasal 1868 Burgerlijk Wetboek (Staatsblad 1847 Nomor 23).

${ }^{17}$ Habib Adjie, Hukum Notaris Indonesia, Tafsir Tematik Terhadap UU 30 Tahun 2004 Tentang Jabatan Notaris, Bandung:Refika Aditama, 2008, h. 120.

${ }^{18}$ Ibid.

19 C.A. Kraan, De Authentieke Akte, Amhem:Gouda Quint BV, 1984, h. 143, 201, sebagaimana mengutip Habib Adjie, Op. Cit., h. 27. 
Berdasar penjabaran diatas, maka dapat diketahui bahwa APHT merupakan akta otentik berdasarkan ketentuan dalam UU No. 4/1996 dan juga pemenuhan karakteristiknya sebagai akta otentik, yang mana berfungsi sebagai salah satu syarat sah lahirnya Hak Tanggungan dan juga dapat melindungi kreditor selama proses berlangsungnya Hak Tanggungan. APHT sebagai akta otentik ini mempunyai kekuatan hukum yang sempurna, dan tentu saja mempunyai kekuatan pembuktian yang sempurna pula sebagaimana dikemukakan oleh Jusuf Patrianto Tjahjono yaitu:

Nilai kekuatan pembuktian yang melekat pada akta otentik diatur dalam Pasal 1870 BW jo. Pasal 285 RGB adalah sempurna (volledig bewijskracht) dan mengikat (bidende bewijskracht); sehingga akta otentik dapat berdiri sendiri tanpa memerlukan bantuan atau dukungan alat bukti yang lain, dengan kata lain akta otentik yang berdiri sendiri menurut hukum telah memenuhi ketentuan batas minimal pembuktian. ${ }^{20}$

Dalam pembebanan Hak Tangungan, diatur jelas dalam Pasal 11 UU No. 4/1996 bahwa pembebanannya wajib didahului dengan APHT, dengan tidak dicantumkannya secara lengkap hal-hal yang disebut dalam APHT, maka mengakibatkan akta yang bersangkutan itu batal demi hukum. Dalam Pasal 11 ayat (1) jo. Penjelasa Pasal 11 ayat (1) UU No. 4/1996, dapat diketahui bahwa halhal yang wajib dicantumkan dalam APHT adalah:

a. Nama dan identitas pemegang dan pemberi Hak Tanggungan. Apabila Hak Tanggungannya dibebankan pula pada benda-benda yang merupakan satu kesatuan dengan tanah milik orang perseorangan atau badan hukum lain daripada pemegang hak atas tanah, pemberi Hak Tanggungan adalah pemegang hak atas tanah bersama-sama pemilim benda tersebut;

b. Domisili pihak-pihak pemegang dan pemberi Hak Tanggungan, dan apabila di antara mereka ada yang berdomisili di luar Indonesia, baginya harus pula dicantumkan suatu domisili pilihan di Indonesia, dan dalam hal domisili pilihan itu tidak dicantumkan, kantor Pejabat Pembuat Akta Tanah tempat pembuatan APHT dianggal sebagai domisili yang dipilih;

c. Penunjukan secara jelas utang atau utang-utang yang dijamin pelunasannya dengan Hak Tanggungan dan meliputi juga nama dan identitas debitor yang bersangkutan.

${ }^{20}$ Jusuf Patrianto Tjahjono, Kedudukan Akta Otentik Dalam Sistem Hukum Pembuktian, 2009, h.5. 
d. Nilai tanggungan;

e. Uraian yang jelas mengenai obyek Hak Tanggungan, yaitu meliputi rincian mengenai sertifikat hak atas tanah yang bersangkutan atau bagi tanah yang belum terdaftar sekurang-kurangnya memuat uraian mengenai kepemilikan, letak, batas-batas dan luas tanahnya.

Selain hal-hal yang wajib dicantumkan diatas, dalam APHT dapat dicantumkan janji-janji yang sifatnya fakultatif, dan tidak mempunyai pengaruh terhadap sahnya APHT. Dengan dimuatnya janji-janji itu dalam APHT yang kemudian didaftar pada Kantor Pertanahan, maka janji-janji tersebut juga mempunyai kekuatan mengikat terhadap pihak ketiga. Berdasarkan Pasal 11 ayat (2) jo. Penjelasan Pasal 11 ayat (2) UU No. 4/1996, maka janji-janji yang dimaksud adalah: ${ }^{21}$

a. Janji yang membatasi kewenangan pemberi Hak Tanggungan untuk menyewakan obyek Hak Tanggungan dan/atau menentukan atau mengubah jangka waktu sewa dan/atau menerima uang sewa dimuka, kecuali dengan persetujuan tertulis terlebih dahulu dari pemegang Hak Tanggungan;

b. Janji yang membatasi kewenangan pemberi Hak Tanggungan untuk mengubah bentuk atau susunan obyek Hak Tanggungan kecuali dengan persetujuan tertulis terlebih dahulu dari pemegang Hak Tanggungan;

c. Janji yang memberikan kewenangan kepada pemegang Hak Tanggungan untuk mengelola obyek Hak Tanggungan berdasarkan Ketetapan Ketua Pengadilan Negeri yang daerah hukumnya meliputi letak obyek Hak Tanggungan apabila debitor sungguh-sunguh cidera janji;

d. Janji yang memberikan kewenangan kepada pemegang Hak Tanggungan untuk menyelamatkan obyek Hak Tanggungan, jika hal itu diperlukan untuk pelaksanaan eksekusi atau hak untuk mencegah menjadi hapusnya atau dibatalkannya hak yang menjadi obyek Hak Tanggungan karena tidak dipenuhi atau dilanggarnya ketentuan undang-undang;

e. Janji bahwa pemegang Hak Tanggungan pertama mempunyai hak untuk menjual atas kekuasaan sendiri obyek Hak Tanggungan apabila debitor cidera janji;

f. Janji yang diberikan oleh pemegang Hak Tanggungan pertama bahwa obyek Hak Tanggungan tidak akan dibersihkan dari Hak Tanggungan;

g. Janji bahwa pemberi Hak Tanggungan tidak akan melepaskan haknya atas obyek Hak Tanggungan tanpa persetujuan tertulis terlebih dahulu dari pemegang Hak Tanggungan;

\footnotetext{
${ }^{21}$ Herowati Poesoko, Op. Cit., h. 79.
} 
h. Janji bahwa pemegang Hak Tanggungan akan memperoleh seluruh atau sebagian dari ganti rugi yang diterima pemberi Hak Tanggungan untuk pelunasan piutangnya apabila obyek Hak Tanggungan dilepaskan haknya oleh pemberi Hak Tanggungan atau dicabut haknya untuk kepentingan umum.

i. Janji bahwa pemegang Hak Tanggungan akan memperoleh seluruh atau sebagian dari uang asuransi yang diterima pemberi Hak Tanggungan untuk pelunasan piutangnya, jika obyek Hak Tanggungan diasuransikan.

j. Janji bahwa pemberi Hak Tanggungan akan mengosongkan obyek Hak Tanggungan pada waktu eksekusi Hak Tanggungan;

k. Janji bahwa sertifikat hak atas tanah yang telah dibubuhi catatan pembebanan Hak Tanggungan tetap berada di tangan kreditor sampai seluruh kewajiban debitor dipenuhi sebagaimana mestinya.

Pencantuman janji-janji dalam suatu hubungan kontraktual adalah wajar, hal ini karena adanya asas kebebasan berkontrak yang berdasar pada Pasal 1338 BW, dalam pembebanan jaminan Hak Tanggungan, diberikan satu batasan janji yang dilarang, yaitu janji untuk memiliki barang, hal ini terlihat dari pengaturan Pasal 12 UU No. 4/1996 yang menegaskan:

Janji yang memberikan kewenangan kepada pemegang Hak Tanggungan untuk memiliki obyek Hak Tanggungan apa-bila debitor cidera janji, batal demi hukum.

Penjelasan Pasal 12 UU No. 4/1996 mengemukakan alasan dibatasinya janji untuk memiliki obyek jaminan, yaitu:

Ketentuan ini diadakan dalam rangka melindungi kepentingan debitor dan pemberi Hak Tanggungan lainnya, terutama jika nilai obyek Hak Tanggungan melebihi besarnya utang yang dijamin. Pemegang Hak Tanggungan dilarang untuk secara serta merta men-jadi pemilik obyek Hak Tanggungan karena debitor cidera janji. Walaupun demikian tidaklah dilarang bagi pemegang Hak Tang-gungan untuk menjadi pembeli obyek Hak Tanggungan asalkan melalui prosedur yang diatur dalam Pasal 20 UUHT.

Menurut Herowati Poesoko, larangan dalam UU No. 4/1996 ini tercermin dari ketentuan Hipotek, karena dahulu pembebanan jaminan pada hak atas tanah dikuasai oleh Hipotek. Dalam akta Hipotek dilarang memuat kalusula milik beding seperti tersebut dalam Pasal 1178 ayat (1) BW, yang antara lain menyatakan segala janji dengan mana kreditor dikuasakan memiliki benda yang 
diberikan dalam Hipotek adalah batal. ${ }^{22}$ Juga janji-janji ini sifatnya adalah mengikat dan tidak dapat ditarik kembali dan tidak akan berakhir oleh sebabsebab yang disebutkan dalam Pasal 1813 BW, kecuali hutang debitor telah dilunasi.

\section{Pemberian Kuasa Sebagai Upaya Perlindungan Kreditor}

Pada bahasan sebelumnya diatas, telah disebutkan bahwa hilangnya hak atas tanah itu sangat beresiko membawa kreditor kedalam posisi yang sangat rawan bahkan merugikan, untuk itu perlu dilakukan upaya oleh kreditor agar kreditor tetap mendapatkan perlindungan hukum yang optimal.

Upaya hukum yang dapat ditempuh kreditor dapat terfasilitasi dengan adanya janji-janji yang sifatnya fakultatif yang terdapat dalam Pasal 11 ayat (2) UU No. 4/1996. Berkenaan dengan hilangnya hak atas tanah, maka upaya perlindungan kreditor terlihat difasilitasi dengan janji fakultatif yang berupa janji untuk menyelamatkan obyek Hak Tanggungan dan juga janji untuk diterimanya seluruh atau sebagian ganti rugi.

Kejadian tertentu terhadap obyek Hak Tanggungan, dapat membuat nilai obyek Hak Tanggungan menurun hingga saat eksekusi nanti tidak dapat menutupi semua hutang debitor, bahkan juga dapat berakibat hapusnya Hak Tanggungan. Hal ini dapat terjadi apabila lewatnya batas waktu hak atas tanah yang dibebani Hak Tanggungan tersebut, juga apabila pihak yang sedang menguasai obyek Hak Tanggungan tersebut tidak mempunyai kepedulian atau kurang melakukan tindakan-tindakan pencegahan atau penyelamatan, juga perawatan obyek Hak Tanggungan, sehingga dapat membuat nilai obyek Hak Tanggungan turun.

Hal-hal tersebut diatas itu dapat diantisipasi dengan pemberian kuasa kewenangan kepada kreditor (pemegang Hak Tanggungan) untuk melakukan tindakan-tindakan penyelamatan obyek jaminan Hak Tanggungan dan juga kewenangan untuk melakukan tindakan agar hak atas tanah tidak hilang kepemilikannya dengan secara mandiri memperpanjang masa berlaku obyek hak

\footnotetext{
${ }^{22}$ Ibid.
} 
atas tanah yang sedang dibebani Hak Tanggungan itu. Inilah sebenarnya fungsi dari janji untuk menyelamatkan obyek Hak Tanggungan yang dapat dicantumkan dalam APHT sebagai upaya perlindungan kreditor bilamana hak atas tanah itu hilang dan mengakibatkan Hak Tanggungan berakhir. Bilamana hak atas tanah yang sedang dibebani Hak Tanggungan itu sudah tidak mungkin diselamatkan lagi dari dibatalkannya hak atas tanah itu, maka perlindungan hukum kreditor yaitu dengan menerima ganti rugi, hal mana ini menjadi fungsi dari janji pemberian ganti rugi yang tertera dalam APHT.

Kedua janji diatas merupakan suatu wujud perlindungan hukum bagi kreditor berkaitan dengan rawannya hak atas tanah itu hilang, kedua janji itu sifatnya fakultatif, bilamana para pihak tidak sepakat maka tidak akan mengurangi keabsahan APHT. Kedua janji tersebut berlaku untu hak atas tanah berupa Hak Guna Bangunan, Hak Guna Usaha dan Hak Pakai, karena ketiga hak atas tanah itulah yang memiliki batas masa berlakunya seperti telah dijabarkan pada bahasan sebelumnya. Memperpanjang atau memperbaharui hak atas tanah itu mememrlukan biaya yang tidak sedikit, dalam Pasal 11 ayat (2) UU No. 4/1996 tidak disebutkan siapa yang harus menanggung biayanya, namun sepatutnya biaya perpanjangan dan pembaharuan hak atas tanah itu ditanggung oleh pemberi Hak Tanggungan (debitor) karena kewajiban pembayaran hak atas tanah pada asasya menjadi tanggungan pemilik atau pemegang hak atas tanah yang bersangkutan.

\section{Tanggung Gugat Debitor}

Berkaitan dengan hilangnya atau hapusnya hak atas tanah, maka bentuk tanggung gugat debitor terhadap kreditor adalah dengan pemberian ganti rugi baik itu seluruhnya, ataupun sebagian, bilamana hak atas tanah tersebut dicabut oleh pemerintah dan pemilik hak atas tanah itu diberikan ganti rugi, maka ganti rugi itulah yang dimaksud dalam janji-janji terseut yang kemudian untuk diberikan kepada kreditor. Hal ini sesuai dengan janji-janji fakultatif yang dapat dicantumkan dalam APHT, yaitu janji bahwa pemegang Hak Tanggungan akan memperoleh seluruh atau sebagian dari ganti rugi yang diterima pemberi Hak Tanggungan untuk pelunasan piutangnya apabila obyek Hak Tanggungan 
dilepaskan haknya oleh pemberi Hak Tanggungan atau dicabut haknya untuk kepentingan umum.

Lain halnya bilamana wujud persil tanahnya yang hilang sehingga mengakibatkan hilangnya hak atas tanah dan hilangnya pula Hak Tanggungan, bilamana hal ini terjadi maka tanggung gugat debitor adalah berkaitan dengan pembayaran asuransi, sebagaimana janji dalam APHT yaitu janji bahwa pemegang Hak Tanggungan akan memperoleh seluruh atau sebagian dari uang asuransi yang diterima pemberi Hak Tanggungan untuk pelunasan piutangnya, jika obyek Hak Tanggungan diasuransikan. Berkaitan dengan asuransi ini, kerapkali janji seperti tersebut diatas itu dirasa belum cukup melindungi pihak kreditor, karena itu biasanya dalam APHT diikuti janji-janji lain yang berkaitan dengan pengasuransian obyek Hak Tanggungan ini, beberapa janji tersebut antara lain:

1. Janji pemberian ganti rugi asuransi langsung dari pihak asuransi kepada kreditor. Hal ini dikarenakan janji yang telah dibuat sebelumnya itu hanyalah memberikan kewenbangan pada kreditor untuk menerima ganti rugi dari perusahaan asuransi, namun pada dasarnya itu tidak cukup, karena pada prinsipnya ganti rugi dari perusahaan asuransi akan langsung diberikan kepada pemilik obyek Hak Tanggungan, bilamana ini terjadi, akan berkompeten untuk pelunasan hutang (pemberian ganti rugi asuransi yang diterima pemilik debitor untuk diserahkan kepada kreditor) itu lebih lama lagi, terutama bila kreditornya lebih dari satu, maka dengan tambahan janji kewenangan diatas, kreditor dapat langsung menerima santunan ganti rugi dari perusahaan asuransi, atau perusahaan asuransi dapat diingatkan untuk memberikan uang ganti rugi kepada kreditor atas dasar kewenangan kreditor yang telah diperjanjikan dengan debitor. Janji ini termasuk pula bilamana ada kejadian yang menilbulkan kerugian oleh pihak asuransi, maka uang ganti rugi tersebut akan diterima oleh kreditor.

2. Janji kewenangan untuk menutup asuransi. Janji ini dikarenakan janji asuransi terkait Hak Tanggungan itu sebenarnya sudah ada dalam blangko APHT, namun perbuatan debitor untuk mengasuransikan obyek Hak 
Tanggungan itulah yang belum tentu ada, sekalipun dalam UU No. 4/1996 diwajibkan untuk mengasuransikan obyek Hak Tanggungan. Hal ini untuk mengantisipasi kemungkinan kelalaian debitor serta sekaligus memberikan kuasa kepada kreditor agar dapat atas nama pemberi jaminan itu menutup perjanjian asuransi, untuk suatu jumlah dan pada perusahaan asuransi yang dipandang baik oleh kreditor.

3. Janji kewenangan untuk memilih perusahaan asuransi yang dipandang baik dan menentukan besaran uang yang dipandang perlu. Hal ini karena tidak cukup bilamana debitor mengasuransikannya di tempat yang asal murah dan tanpa memperhatikan bonadifitasnya. Maka dari itu atas nama debitor, kreditor diberikan kewenangan untuk bertindak menentukan halhal diatas.

4. Janji pembayaran premi asuransi oleh debitor.

Berbeda halnya bila tidak berkaitan dengan hak atas tanah hilang, bilamana terkait dengan wanprestasi dari debitor, maka bentuk tanggung gugat debitor adalah eksekusi obyek jaminan.

\section{Eksekusi Obyek Hak Tanggungan}

Eksekusi obyek jaminan kebendaan merupakan salah satu langkah pelunasan hutang, menurut Soedikno Mertokusumo eksekusi adalah: ${ }^{23}$

Eksekusi adalah sebagi pelaksanaan putusan pengadilan yang telah memperoleh kekuatan hukum tetap. Obyek dari eksekusi adalah salinan putusan dan grosse akta (salinan pertama dari akta otentik). Grosse akta dapat dieksekusi karena memuat titel eksekutorial, sehingga grosse akta dapat disamakan kekuatannya dengan putusan pengadilan yang telah berkekuatan hukum tetap ${ }^{24}$.

Ditambahkan oleh Soedikno Mertokusumo, bahwa terdapat beberapa jenis pelaksanaan putusan (eksekusi) yaitu sebagai berikut: ${ }^{25}$

${ }^{23}$ Soedikno Mertokusumo, Hukum Acara Perdata Indonesia, Yogyakarta:Liberty,1998, h.

${ }^{24}$ Subekti, Hukum Acara Perdata, Jakarta:BPHN, 1977, h. 128.

${ }^{25}$ Soedikno Mertokusumo, Loc. Cit. 
1. Eksekusi putusan yang menghukum pihak yang dikalahkan untuk membayar sejumlah uang. Prestasi yang diwajibkan adalah membayar sejumlah uang. Eksekusi ini diatur dalam Pasal 196 HIR (Pasal 208 $\mathrm{RBg}$;

2. Eksekusi putusan yang menghukum orang untuk melakukan suatu perbuatan. Hal ini diatur dalam Pasal 225 HIR (Pasal 259 RBg). Orang tidak dapat dipaksakan untuk memenuhi prestasi yang berupa perbuatan. Akan tetapi pihak yang dimenangkan dapat minta kepada hakim agar kepentingan yang akan diperolehnya itu dinilai dengan uang.

3. Eksekusi riil. Eksekusi ini merupakan pelaksanaan prestasi yang dibebankan kepada debitor oleh putusan hakim secara langsung. Eksekusi ini adalah pelaksanaan putusan yang menuju kepada hasil yang sama seperti apabila dilaksanakan secara sukarela oleh pihak yang bersangkutan. Dengan eksekusi riil, maka yang berhak lah yang menerima prestasi. Prestasi yang terhutang seperti pembayaran sejumlah uang, melakukan suatu perbuatan tertentum tidak berbuat, dan menyerahkan benda. Maka dari itu ganti rugi dan uang paksa bukanlah termasuk eksekusi riil. Eksekusi ini diatur sedikit dalam HIR (hanya dalam penjualan lelang) Pasal 200 ayat 11, dan dalam RBg Pasal 218 ayat 2, selebihnya diatur dalam Pasal $1033 \mathrm{RV}$.

4. Eksekusi langsung. Disamping ketiga jenis eksekusi diatas, masih dikenal apa yang dinamakan "parate executie" atau eksekusi langsung. Parate executie terjadi apabila seorang kreditor menjual barang-barang tertentu milik debitor tanpa mempunyai titel eksekutorial (Pasal 1155, 1175 ayat (2) BW).

Eksekusi obyek Hak Tanggungan diatur dalam Pasal 20 UU No. 4/1996, yang ditegaskan dalam ayat (1):

Apabila debitor cidera janji, maka berdasarkan:

a. Hak pemegang Hak Tanggungan pertama untuk menjual obyek Hak Tanggungan sebagaimana dimaksud dalam Pasal 6, atau

b. Titel eksekutorial yang terdapat dalam sertipikat Hak Tanggungan sebagaimana dimaksud dalam Pasal 14 ayat (2), obyek Hak Tanggungan dijual melalui pelelangan umum menurut tata cara yang ditentukan dalam peraturan perundang-undangan untuk pelunasan piutang pemegang Hak Tang-gungan dengan hak mendahulu dari pada kreditor-kreditor lainnya.

Dan dalam Pasal 20 ayat (2) UU No. 4/1996 dijelaskan:

Atas kesepakatan pemberi dan pemegang Hak Tanggungan, penjualan obyek Hak Tanggungan dapat dilaksanakan di bawah tangan jika dengan demikian itu akan dapat diperoleh harga tertinggi yang menguntungkan semua pihak. 
Berdasarkan ketentuan Pasal 20 UU No. 4/1996 diatas, dapat ditarik kesimpulan bahwa eksekusi Hak Tanggungan dapat dilakukan dengan 3 (tiga) cara, yaitu:

1. Pemegang Hak Tanggungan pertama untuk menjual obyek Hak Tanggungan atas kuasanya sendiri melali pelelangan umum, sebagaimana dimaksud dalam Pasal 6 UU No. 4/1996. Hal mana dikenal juga sebagai Parate Executie.

2. Eksekui berdasarkan titel eksekutorial yang terdapat pada sertifikat Hak Tanggungan. Irah-irah yang dicantumkan dalam sertifikat Hak Tanggungan, sebagaimana yang dimaksud dalam Pasal 14 ayat (2) UUHT, yang berbunyi "DEMI KEADILAN BERDASARKAN KETUHANAN YANG MAHA ESA” berlaku sebagi titel eksekutorial dan menegaskan adanya kekuatan eksekutorial pada sertifikat Hak Tanggungan tersebut. Sehingga bilamana debitor wanprestasi maka siap untuk di eksekusi seperti halnya sudah mendapatkan putusan pengadilan yang berkekuatan hukum tetap ${ }^{26}$. Melalui titel ini juga obyek Hak Tanggungan dapat dijual melalui pelelangan umum sesuai dengan Hukum Acara Perdata. ${ }^{27}$

3. Eksekusi dibawah tangan, yaitu penjualan obyek Hak Tanggungan yang dilakukan oleh pemegang Hak Tanggungan, jika dengan cara ini diharapkan akan diperoleh harga yang tertinggi. ${ }^{28}$

Berdasarkan penjabaran singkat diatas, maka dapat terlihat perbedaan bentuk tangung gugat debitor bila hak atas tanah hilang (ganti rugi) dan juga bila debitor wanprestasi (eksekusi : parate eksekusi, titel eksekutorial, atau dibawah tangan)

\section{Kesimpulan}

${ }^{26}$ Penjelasan Pasal 14 ayat (2) dan (3) Undang-Undang Nomor 4 Tahun 1996 tentang Hak Tanggungan (Lembaran Negara Republik Indonesia Tahun 1996 Nomor 42, Tambahan Lembaran Negara Republik Indonesia Nomor 3632).

27 Pasal 20 ayat (1) huruf (b) Undang-Undang Nomor 4 Tahun 1996 tentang Hak Tanggungan (Lembaran Negara Republik Indonesia Tahun 1996 Nomor 42, Tambahan Lembaran Negara Republik Indonesia Nomor 3632).

28 Pasal 20 ayat (2) Undang-Undang Nomor 4 Tahun 1996 tentang Hak Tanggungan (Lembaran Negara Republik Indonesia Tahun 1996 Nomor 42, Tambahan Lembaran Negara Republik Indonesia Nomor 3632). 
Lembaga jaminan Hak Tanggungan merupakan salah satu lembaga jaminan yang banyak diminati, salah satu alasannya adalah karena tanah merupakan benda tidak bergerak dan merupakan benda modal yang dapat berkembang nilainya. Dibalik keistimewaan itu ternyata posisi kreditor dapat menjadi sangat rawan, hal ini karena Hak Tanggungan itu pembebanannya pada hak atas tanah (HGB, HGU, Hak Pakai, Hak Milik) dan hak atas tanah itu sewaktu-waktu dapat hilang atau hapus baik karena bencana alam atau karena ketentuan undang-undang. Perlindungan kreditor dalam hal rawannya hak atas tanah hilang atau hapus ini yaitu dengan memanfaatkan janji-janji kuasa dalam APHT sebagi penangkal resiko bagi kreditor, sehingga kreditor memiliki kewenangan lebih dalam bertindak pada obyek Hak Tanggunan yang bersangkutan. Sedangkan tanggung gugat debitor bilamana hak atas tanah itu hapus karena ketentuan undang-undang, yaitu dengan pemberian kepada kreditor uang ganti rugi yang diterima debitor dari pemerintah, atau bilamana wujud tanah itu hilang karena bencana alam, maka bentuk tanggung gugat debitor adalah dengan pemberian kepada kreditor uang ganti rugi dari pihak asuransi. Berbeda halnya dengan bilamana debitor wanprestasi, bilamana wanprestasi maka tanggung gugatnya adalah dalam bentuk eksekusi obyek jaminan, dimana untuk Hak Tanggungan ini eksekusinya berupa 3 (tiga) macam, yaitu Parate Executie, titek eksekutorial dan penjualan dibawah tangan. 


\section{Daftar Bacaan}

\section{Buku}

Adjie, Habib, Hukum Notaris Indonesia, Tafsir Tematik Terhadap UU 30 Tahun 2004 Tentang Jabatan Notaris, Bandung, Refika Aditama, 2008.

Badrulzaman, Mariam Darus, Bab-Bab Tentang Hypotheek, Bandung, Citra Aditya Bakti, 1991.

, Bab-Bab Tentang Credietverband, Gadai, Fiducia, Bandung Alumni, 1987.

C.A. Kraan, De Authentieke Akte, Arnhem, Gouda Quint BV, 1984.

Djumhana, Muhammad, Hukum Perbankan di Indonesia, Bandung, Citra Aditya Bakti, 2000.

Gautama, Sudargo (Gauw Giok Siong), Tafsiran Undang-Undang Pokok Agraria, Jakarta, Keng Po, 1963.

Mertokusumo, Soedikno, Hukum Acara Perdata Indonesia, Yogyakarta, Liberty, 1998.

Patrianto, Jusuf, T., Kedudukan Akta Otentik Dalam Sistem Hukum Pembuktian, 2009.

Poesoko, Herowati, Dinamika Hukum Parate Eksekusi Obyek Hak Tanggungan, Yogyakarta, Aswaja Pressindo, 2012.

Satrio J, Hukum Jaminan Hak-Hak Kebendaan, Bandung, Citra Aditya Bakti, 1996.

, Hukum Jaminan, Hak Jaminan Kebendaan, Bandung, Citra Aditya Bakti, 2007.

Sjahdeini, Sutan Remy, Hak Tanggungan - Asas-Asas, Ketentuan Pokok dan Masalah Yang Dihadapi Oleh Perbankan, Bandung, Alumni, 1999.

Sofwan, Sri Soedewi, Machsoen, Hukum Jaminan di Indonesia Pokok-Pokok Hukum Jaminan dan Jaminan Perorangan, Yogyakarta, Liberty Offset, 1980.

, Hukum Benda, Yogyakarta, Liberty Offset, 1981.

, Hukum Perdata: Hukum Benda, Yogyakarta, Liberty, 1974. 
Subekti, Hukum Acara Perdata, Jakarta, BPHN, 1977.

Usman, Rachmadi, Hukum Jaminan Keperdataan, Jakarta, Sinar Grafika, 2008.

\section{Perundang-Undangan :}

Undang-Undang No. 30 Tahun 2004 tentang Jabatan Notaris

Undang-Undang No. 4 Tahun 1999 tentang Hak Tanggungan

Undang-Undang No. 5 Tahun 1960 tentang Pokok-Pokok Agraria

Peraturan Pemerintah No. 40 Tahun 1996 tentang Hak Guna Usaha, Hak Guna Bangunan dan Hak Pakai atas Tanah 